\title{
PENGARUH RASIO KREDIT BERMASALAH TERHADAP PROFITABILITAS BANK UMUM SELAMAPANDEMI COVID-19: KASUS INDONESIA
}

\author{
Febrian Ahmad Sulton, Givantoro Agma Ardira, dan H Hersugondo \\ Departemen Manajemen Fakultas Ekonomika dan Bisnis Universitas Diponegoro \\ febrian.sulton99@gmail.com; givantoroagmaa@gmail.com \\ hersugondo@lecturer.undip,ac.id
}

\begin{abstract}
The COVID-19 pandemic has had an impact on the economy. The existence of the pandemic has affected the increase in bad loans in the banking industry. This study aims to prove whether COVID-19 has an impact on the risk of non-performing loans and the profitability of commercial banks in Indonesia. This study examines the effect of loan to deposit ratio (LDR) on return on assets (ROA) and return on equity (ROE). Company size, deposits, equity, profitability as control variables to calculate the risk of non-performing loans. The analytical method used is multiple linear regression. The population uses banking in Indonesia. The data is sourced from financial reports for the first quarter to the third quarter of 2020. The data is obtained through Bloomberg. The results of the analysis found that during the Covid-19 pandemic, credit risk had an effect on increasing bank profitability. The size of the bank also affects the increase in bank profitability.
\end{abstract}

Keyword: Covid-19, Non-Performing Loan, Profitability.

\begin{abstract}
Abstrak
Pandemi Covid-19 berdampak pada sektor ekonomi. Adanya pandemi tersebut berpengaruh terhadap peningkatan kredit macet di industri perbankan. Penelitian ini bertujuan untuk membuktikan apakah COVID-19 memiliki dampak pada risiko kredit bermasalah (nonperforming loan) dan profitabilitas bank umum di Indonesia. Penelitian ini menguji pengaruh loan to deposit ratio (LDR) terhadap return on asset (ROA) dan return on equity (ROE). Ukuran perusahaan, deposito, equity, profitabilitas sebagai variabel kontrol untuk menghitung nilai risiko kredit bermasalah. Metode analisis yang digunakan adalah regresi linier berganda. Populasi menggunakan perbankan di Indonesia. Data bersumber dari laporan keuangan selama triwulan 1 sampai triwulan 3 tahun 2020. Data diperoleh melalui Bloomberg. Hasil analisis ditemukan bahwa pada masa pandemi Covid-19, risiko kredit berpengaruh terhadap peningkatan profitabilitas bank. Ukuran bank juga mempengaruhi peningkatan profitabilitas bank.
\end{abstract}

Kata Kunci: Covid-19, Non-Performing Loan, Profitabilitas.

\section{PENDAHULUAN}

Wabah virus yang akhir-akhir ini marak diperbincangkan yaitu Covid-19 (juga dikenal sebagai SARS-CoV-2) oleh organisasi kesehatan dunia (WHO), telah dinyatakan sebagai pandemi global. Pada akhir Februari 2020, dunia mulai digemparkan dengan wabah ini yang mana menyebabkan berdampaknya sektor ekonomi yang menurun secara drastis.

Pada sisi dunia perbankan, bank dapat terkena berbagai tingkat risiko sebagai akibat dari 
pinjaman yang berlebihan. Meskipun ada beberapa ketentuan yang memadai untuk mengurangi risiko ini, ketika rasio Non-Performing Loan (NPL) tinggi, risiko menjadi lemah. Tingkat risiko ini juga berdampak terhadap kemampuan debitur dalam melunasipinjamannya yang bersumber dari kredit bank. Untuk itu dari pihak perbankan mulai berhati- hati dalam menyalurkan kredit guna menghindari risiko kredit macet. Kesulitan dalam membayar peminjam membuat beberapa bank, terutama yang berskala kecil, mengalami kesulitan. Terjadinya kasus kredit macet di beberapa bank merupakan pertanda bahwa kegiatan operasional bank sedang tidak sehat. Sedangkan pada dasarnya terdapat cara penyelamatan terhadap kredit macet, terdapat 5 cara yang digunakan yaitu (1) rescheduling (penjadwalan ulang), (2) reconditioning (persyaratan ulang), (3) restructuring (penataan ulang), (4) kombinasi 3 metode sebelumnya, dan (5) penyitaan jaminan.

Pandemi COVID-19 merupakan faktor eksternal di luar kemampuan debitur untuk mengendalikan, yang menyebabkan kesulitan bagi debitur untuk melunasi kredit yang berasal dari kredit bank. Performa kredit buruk juga bisa disebabkan oleh bencana alam sepertiwabah virus corona. Mantan Gubernur Bank Indonesia, Burhanuddin Abdullah dalam kutipan Iswi Haryani menyatakan bahwa kredit macet disebabkan oleh bencana alam atau keadaan darurat di luar kemampuan manusia (Hariyani, 2013). Dampak COVID-19 berpengaruh terhadap peningkatan kredit macet di industri perbankan (Novalina, 2020).

Mengenai tentang laba atau keuntungan. Laba atau keuntungan dianggap sebagai sebuah kekuatan tambahan yang membuat bisnis tetap berjalan. Laba dapat mencerminkan kemajuan perusahaan dan, pada saat yang sama, menguji efisiensi kemajuan tersebut (Vinh, 2017; Krakah dan Ameyaw, 2010; Karim dkk, 2017). Para ekonom bahkan menganggap labasebagai mata ajaib yang mencerminkan seluruh gambaran bank, termasuk semua aspek dari keseluruhan operasi.

Adanya wabah covid-19, pemerintah mengeluarkan Peraturan Pemerintah Pengganti Undang-Undang (Perppu) No. 1/2020 tentang kebijakan keuangan negara dan stabilitas sistem keuangan untuk penanganan pandemi covid-19 dan atau dalam rangka menghadapi ancaman yang membahayakan perekonomian nasional dan atau stabilitas sistem keuangan. Salah satu kebijakan dalam peraturan tersebut adalah relaksasi ketentuan retrukturisasi kredit yang dilakukan oleh Otoritas Jasa Keuangan (OJK). Restrukturisasi bertujuan menekan rasio kredit macet bank, sekaligus mengurangi biaya pencadangan yang perlu dibentuk.

Berdasarkan studi kasus COVID-19, analisis akan dilakukan untuk membuktikan apakah COVID-19 memiliki dampak pada tingkat NPL dan profitabilitas bank umum di Indonesia. 


\section{TINJAUAN PUSTAKA DAN PENGEMBANGAN HIPOTESIS}

\section{Profitabilitas}

Profitabilitas merupakan ukuran relatif yang mengacu pada kemampuan suatu entitas untuk memperoleh laba (Tulsian, 2014). Profitabilitas entitas tersebut adalah hasil akhir dari berbagai kebijakan, bersama dengan banyak keputusan yang dibuat oleh entitas itu sendiri. Profitabilitas dianggap sebagai ukuran utama yang mencerminkan keberhasilan keseluruhan bisnis dan menunjukkan seberapa efektif bisnis telah menggunakan sumber dayanya. Profitabilitas juga didefinisikan sebagai kemampuan memperoleh pengembalian dari suatu investasi tertentu. Atau merupakan kemampuan entitas untuk menghasilkan pendapatan yang melebihi biaya. Dengan demikian, peningkatan laba tidak serta merta menyimpulkan bahwa profitabilitas entitas tertentu akan meningkat. Salah satu fitur penting dari konsep profitabilitas adalah sifatnya yang bervariasi. Profitabilitas bukanlahfenomena konstan dan tak tergoyahkan yang tetap tidak berubah oleh determinannya; sebaliknya, itu adalah salah satu yang bervariasi.

Banyak indikator yang dapat digunakan untuk mengukur profitabilitas. Menurut Goudreau dan Whitehead (1989) dan Uchendu (1995), di antara indikator- indikator, return on assets (ROA), return on equity (ROE) dan net interest margin (NIM) adalah tiga indikator terbaik. Menurut Hancock (1989) pengukuran profitabilitas menggunakan ROE dan NIM (Odufulu, 1994).

\section{Return on Assets (ROA)}

ROA merupakan rasio (persentase) antara pendapatan bersih dengan total aset. ROA menunjukkan laba yang dihasilkan dari aset yang diinvestasikan. Untuk perusahaan publik, ROA akan sangat bergantung pada industri dan dapat bervariasi secara signifikan. Untuk alasan ini, cara terbaik menggunakan ROA untuk pengukuran komparatif adalah membandingkan dengan ROA sebelumnya dari perusahaan yang sama atau serupa. Baik hutang dan ekuitas terdiri dari aset perusahaan dan kedua jenis aset tersebut digunakan untuk mendanai operasi perusahaan. Dengan melihat rasio ROA, investor dapat memiliki gambaran apakah perusahaan secara efektif mengubah asetnya menjadi laba bersih atau tidak. ROA yang lebih tinggi berarti kinerja yang lebih baik karena menunjukkan bahwa perusahaan menghasilkan lebih banyak dengan pengeluaran yang lebih sedikit. ROA adalah indikator profitabilitas yang paling sering digunakan (Trujillo-Ponce, 2013).

\section{Return on Equity (ROE)}

Return on equity sangat mirip dengan ROA dan banyak digunakan dalam banyak 
penelitian untuk mewakili profitabilitas saja atau dengan ROA dan NIM. Ini adalah jumlah pengembalian atau laba bersih dalam bentuk persentase ekuitas pemegang saham. ROE juga dapat dianggap sebagai indikator profitabilitas karena mengungkapkan berapa banyak keuntungan yang diperoleh perusahaan dengan jumlah uang yang telah diinvestasikan pemegang saham.

Laba bersih dimasukkan untuk seluruh tahun fiskal (sebelum dividen dibagikan kepada pemegang saham tetapi setelah saham preferen) dan saham preferen tidak termasuk dalam ekuitas pemegang saham. ROE paling berguna ketika membandingkan profitabilitas dua atau lebih perusahaan dalam industri yang sama diperlukan. ROE juga memberikan sinyal keberhasilan finansial karena menunjukkan apakah entitas memperoleh laba tanpa menuangkan modal ekuitas baru ke dalam bisnis. Di sisi lain, ROE juga bertindak sebagai batas kecepatan tingkat pertumbuhan, yang digunakan oleh pengelola uang untuk memprediksi potensi pertumbuhan.

\section{Non-Performing Loan (NPL)}

Non-Performing Loan (NPL) dikenal juga dengan Non-Performing Asset (NPA). NPL mengacu pada pinjaman yang tidak dapat dilunasi dan saldonya tetap sama dalam jangka waktu yang lama. Biasanya, jika pembayaran terlambat selama 90 hari, itu akan diklasifikasikan sebagai non-performing. NPL mencerminkan beberapa aspek kinerja bank. Tingkat NPL dapat dianggap sebagai indikator terbaik untuk kesehatan industri perbankan (Symss dkk, 2018).

Metode untuk mengukur kredit bermasalah (NPL) menggunakan metode kuantitatif dan kualitatif. Metode kuantitatif dapat digunakan untuk menghitung probabilitas default. Menurut Basel II, bank umum diperbolehkan menggunakan metode Foundation Internal Rating Based (F-IRB) dalam mengevaluasi dan menghitung risiko kredit. Literatur F-IRB didasarkan pada model stimulasi yang diterapkan pada risiko kredit, di mana probabilitas gagal bayar pelanggan dievaluasi berdasarkan perbedaan antara nilai aset agunan dan nilai nominal pinjaman. Nilai aset bervariasi dari waktu ke waktu, dipengaruhi oleh faktor acak seperti perubahan tren pasar atau kebijakan. Probabilitas gagal bayar akan terjadi ketika nilai aset agunan lebih rendah dari nilai nominal pinjaman tersebut. Dalam mengukur NPL, bank harus mengikuti dua langkah utama. Langkah pertama adalah mengidentifikasi nilai aset berisiko. Bank harus mengkategorikan pelanggan ke dalam kelompok seperti: perusahaan, pemerintah, bank, individu dansebagainya. Selanjutnya adalah mengidentifikasi komponen risiko, antara lain: Probability of default (PD): mengukur probabilitas risiko kredit dalam suatu periode waktu (biasanya satu tahun); Loss given default (LGD): kerugian yang terjadi jika nasabah melakukan 
wanprestasi,yang digambarkan sebagai persentase di atas nilai nominal pinjaman. Bank harus memperkirakan LGD ini untuk jumlah yang harus mereka klaim dari setiap individu, perusahaan, dan bank lain; exposure at default (EAD): jumlah total hutang pada saat pelanggan tidak dapat membayar lagi; dan jatuh tempo efektif (M): jatuh tempo yang ditetapkan 2,5 tahun menurut IRB dasar, tidak boleh lebih dari 5 tahun.

Metode F-IRB mensyaratkan bahwa tarif LGD yang ditetapkan untuk klaim dari individu- individu ini harus sebesar 45\%. Demikian pula, pendekatan standar bank dapat mencatat dampak mitigasi risiko aset agunan dengan menyesuaikan nilai pengurangan risiko LGD atauEAD. Namun, untuk menghindari duplikasi, penyesuaian nilai risiko hanya dilakukan satu kali, hanya dengan LGD atau hanya dengan EAD.

Langkah kedua adalah menyesuaikan nilai ekuitas berdasarkan selisih antara total expected loss value (EL) dan total cadangan risiko kredit. Untuk menentukan nilai kerugian yang diharapkan, bank harus mengakumulasikan nilai kerugian yang diharapkan dari semua pinjaman yang termasuk dalam kelompok risiko yang berbeda; (ii) menentukan nilai total provisi risiko kredit dengan total semua jenis provisi (termasuk provisi khusus, provisi umum untuk risiko nasional, provisi umum untuk pinjaman yang diberikan dan piutang); nilai penyisihan khusus untuk kontribusi ekuitas dan efek sekuritisasi tidak termasuk dalam penyisihan kerugian kredit; (iii) membandingkan total nilai EL dan total nilai provisi risiko kredit dan melakukan penyesuaian langsung terhadap selisih nilai ekuitas dari kedua nilai tersebut. Metode F-IRB akan didasarkan pada kerugian tak terduga dan diharapkan. Fungsi koefisien risiko digunakan sebagai dasar untuk menghitung kebutuhan modal yang diperlukan untuk kerugian yang tidak diinginkan (UL). Kerusakan yang diantisipasi sebelum EL akan dipertimbangkan secara terpisah. Dalam metode F-IRB, keandalan yang dibutuhkan adalah $99,9 \%$, artinya $0,1 \%$ dari probabilitas ekuitas bank sendiri tidak akan cukup untuk mengimbangi kerugian yang tidak terduga dan kali ini bank akan jatuh ke dalam kebangkrutan.

Selain metode berdasarkan penggarukan internal dasar, Basel II Treaty juga memungkinkan bank untuk menerapkan metode berdasarkan Advanced Internal Ratings Based (A-IRB)untuk mengukur penggunaan risiko kredit. Pada metode A-IRB, estimasi LGD dapat mencerminkan efektivitas dampak mitigasi risiko dari aktivitas penjaminan dan produk kredit derivatif dengan menyesuaikan PD atau LGD. LGD harus dihitung sesuai dengan persentase kerugian akibat wanprestasi terhadap EAD. Oleh karena itu, Basel Committee memberikan dua pilihan kepada bank, yaitu metode IRB dasar dan metode IRB lanjutan.

Jika IRB dasar digunakan, bank hanya memperkirakan probabilitas default (PD) sendiri dan mengandalkan estimasi pengawas untuk faktor risiko lainnya. Jika IRB lanjutan digunakan, 
bank harus membuat estimasi untuk semua faktor risiko termasuk PD, LGD dan EAD, dan menghitung sendiri variabel $\mathrm{M}$, dan harus mengikuti standar minimum. Untuk metode dasar dan lanjutan, bank harus selalu menggunakan fungsi koefisien risiko sesuai dengan ketentuan khusus dalam perjanjian. Meskipun perhitungan kebutuhan modal minimum hanya untuk mengkompensasi kerugian yang tidak terduga, bank juga harus menanganinya untuk mengkompensasi kerugian yang diharapkan dengan dasar yang sama, termasuk kebijakan harga, redundansi dan pelepasan total.

\section{Teori Portofolio Modern}

Modern Portfolio Theory (MPT) adalah teori yang paling kuat dalam ekonomi yang berhubungan dengan keuangan dan investasi oleh Markowitz (1952). Dikenal sebagai ungkapan "jangan menaruh semua telur Anda dalam satu keranjang”, teori ini mengevaluasi manfaat diversifikasi. Ini adalah teori tentang investasi yang berusaha menjelaskan bagaimana investor dapat meminimalkan risiko dan memaksimalkan keuntungan melalui investasi di berbagai aset. Menurut Atemkeng dan Nzongang (2006), teori tersebut memiliki pendekatan yang paling dekat dan berperan penting dalam kajian tentang kinerja perbankan. Ini menyiratkan bahwa manajemen bank bertanggung jawab atas diversifikasi portofolio dan komposisi portofolio yang diinginkan bank tersebut.

Kemampuan untuk menciptakan keuntungan maksimum sangat tergantung pada kumpulan aset dan kewajiban yang layak dan biaya unit yang dikeluarkan oleh bank untuk memproduksi setiap komponen aset (Atemkeng dan Nzongang, 2006). Sebagai konsekuensinya, bank umum harus mempertimbangkan untuk mengurangi atau meminimalkan risiko gagal bayar dari pengambil kredit dalam pembayaran kembali pinjaman yang menyebabkan kenaikan NPL, yang mempengaruhi profitabilitas.

Konsep diversifikasi pendapatan, mengikuti konsep MPT, menyatakan bahwa tidak hanya bank tetapi juga individu dapat mendiversifikasi portofolio mereka sendiri untuk mengurangi risiko spesifik perusahaan. Singkatnya, teori portofolio modern mendorong kegiatan diversifikasi yang memberikan pendapatan yanglebih stabil dan kemampuan untuk meningkatkan efisiensi manajerial di seluruh produk dan untuk kasus bank komersial, mengurangi NPL dan meningkatkan pengembalian aset (ROA). Teori informasi asimetris merekomendasikan bahwa transparansi dalam memberikan pinjaman sangat penting, jika tidak, baik bank maupun nasabah akan menderita akibat yang tidak diharapkan, terutama bank yang dapat berakhir dengan tingkat NPL yang tinggi.

\section{Pengaruh kredit bermasalah terhadap profitabilitas bank}


Kredit bermasalah dan hubungan profitabilitas telah menjadi pusat studi perbankan karena potensinya untuk kebijakan regulasi. Melihat beberapa penelitian yang telah dilakukan sebelumnya, dapat disimpulkan bahwa NPL dapat berdampak negatif terhadap profitabilitas, atau dengan kata lain, membuat bank menjadi tidak efisien (Demirgüç-Kunt dan Huizinga, 1999). Penelitian tentang profitabilitas bank mulai mempertimbangkan kualitas aset, yang meliputi non-performing assets (NPA). Athanasoglou dkk (2008) menunjukkan bahwa pinjaman dengan kualitas aset yang rendah akan menghasilkan keuntungan yang lebih kecil. Ini sekali lagi menegaskan hubungan negatif antara kredit macetdan kemampuan menghasilkan keuntungan bank.

Hipotesis yang diajukan oleh Berger dan DeYoung (1997) juga mendukung temuan di atas yang menyatakan bahwa semakin baikbank dalam mengelola risiko kreditnya, semakin efisien bank tersebut. Bankir dkk. (2010) menggunakan kumpulan data panel selama periode 1995-2005 untuk 14 bank komersial Korea untuk melakukan penelitian. Hasil tersebut menyiratkan bahwa tingkat NPLberdampak negatif pada produktivitas bank. Bankir dkk. (2010) juga menyatakan dalam penelitian yang sama bahwa ketika pentingnya NPL tidak diperhatikan, bank dapat mengalami kerugian dalam perilaku pemberian pinjaman. Selain itu, jika NPL tidak terkendali, ini akan berdampak buruk pada profitabilitas.

Andries (2011) merekomendasikan solusi bahwa NPL harus dibatasi untuk meningkatkan efisiensi bank. Sekali lagi, hubungan negatif NPL dan profitabilitas terbukti signifikan secara statistik ketika diperiksa antara tahun 2004 dan 2009 di sektor perbankan Eropa Tengah dan Timur. Hasil yang sama diperoleh ketika Trujillo-Ponce (2013) mengevaluasi faktor-faktor penentu produktivitas di antara bank-bank komersial Spanyol dalam periode 10 tahun mulai dari 1999. Dengan sampel 89 bank dan 697 pengamatan, makalah ini membuktikan bahwa NPL berdampak negatif. pada ROA dan ROE pada tingkat signifikansi tertentu. Rasio NPL memiliki hubungan negatif secara statistik dengan profitabilitas bank. Berdasarkan penjelasan tersebut dapat dirumuskan hipotesis sebagai berikut:

Loan to deposit ratio berpengaruh terhadap ROA dan $R O E$ Kerangka pemikiran dapat disajikan pada Gambar 1. 


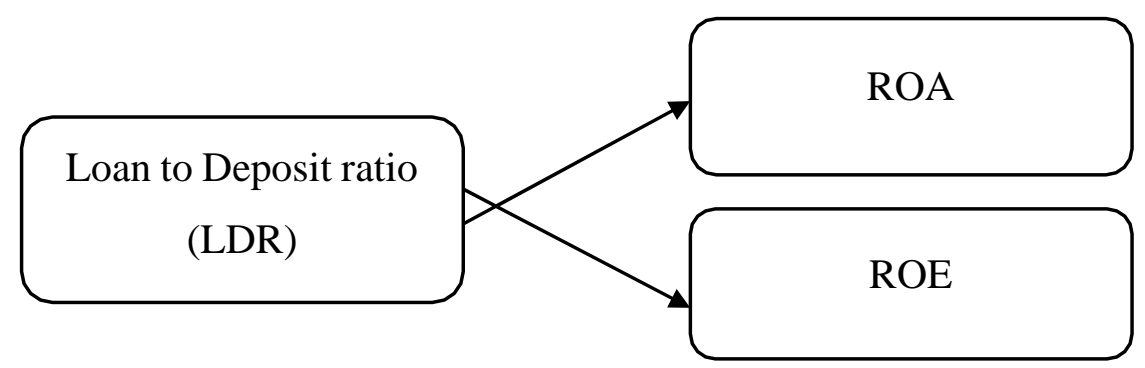

Ukuran perusahaan, deposito, equity, profitabilitas sebagai variable kontrol tambahan guna menghitung nilai risiko kredit bermasalah.

\section{METODE PENELITIAN}

Di dalam studi penelitian ini digunakanlah data perbankan yang mencakup antara kuartal 1 tahun 2020 hingga kuartal 3 tahun 2020, yang merupakan selama periode waktu tersebut di Indonesia masih terdampak parah oleh adanya wabah Covid-19. Selanjutnya, selama ini kredit bermasalah dilaporkan terus tinggi dan belum terselesaikan hingga tahun 2017.

Metode pengumpulan dan pengolahan data: data sekunder pada variabel dalam model penelitian dikumpulkan dari sumber yang dapat dipercaya. Data tersebut diperoleh dari penyedia data perbankan yaitu Bloomberg. Jumlah observasi yang digunakan sebanyak 150 data, yang diperoleh dari laporan keuangan periode kuartal 1 hingga kuartal 3 tahun 2020 dari 35 bank komersial di Indonesia. Variabel yang digunakan profitabilitas (ROA), rasio pinjaman terhadap simpanan (LDR), deposito (Deposit), ukuran bank (BANKSIZE), dan ekuitas (Equity). Indikator pengukuran variabel disajikan pada Tabel 1.

Tabel 1. Ringkasan variabel dalam model penelitian

\begin{tabular}{lll}
\hline Deskripsi & Nama & Rumus Penghitungan \\
\hline $\begin{array}{l}\text { Variabel Dependen } \\
\text { Loan to debt ratio }\end{array}$ & LDR & $\frac{\text { Total pinjaman }}{\text { Total simpanan }}$ \\
\hline $\begin{array}{l}\text { Variabel Independen } \\
\text { Ukuran perusahaan }\end{array}$ & Bank Size & Logaritma (Total asset) \\
\hline Simpanan & Deposito & $\frac{\text { Jumlah uang simpanan } x \text { bunga per tahun } x \text { tenor }}{12}$ \\
\hline Equity & ROE & $\frac{\text { Laba bersih setelah pajak }}{\text { Ekuitas pemegang saham }}$ \\
\hline Profitabilitas bank & ROA & $\frac{\text { Laba bersih setelah pajak }}{\text { Total asset }}$ \\
\hline
\end{tabular}

Rasio kredit bermasalah (NPL): Rasio NPL secara serius mengancam tidak hanya stabilitas keuangan bank umum tetapi juga seluruh sistem keamanan moneter nasional. Ketika kredit macet melebihi batas yang diizinkan (biasanya 5 persen), bank umum akan kehilangan 
sejumlah besar modal. Hal ini mempengaruhi arus kas dan bank akan menjadi tidak likuid, yang mengarah pada kemungkinan kebangkrutan, yang akan mengancam pembangunan berkelanjutan bank serta profitabilitasnya.

Loans to deposit ratio (LDR): Bank memperoleh sebagian besar keuntungannya dari margin bunga bersih (Towpek \& Borhan, 2006). Rasio pinjaman terhadap simpanan dihitung dengan membagi total jumlah pinjaman dengan total simpanan. Abreu dan Mendes (2002) mengumumkan bahwa ada hubungan yang signifikan dan positif secara statistik antara loan to deposit ratio dan profitabilitas bank. Semakin banyak pinjaman yang dapat diberikan bank, semakin tinggi pendapatan yang dapat mereka hasilkan.

Ukuran bank (BANKSIZE): Dihitung dengan total aset bank. Hubungan antara ukuran bank dan profitabilitas bank telah dipelajari di berbagai negara tetapi hasilnya tetap kontroversial. Studi oleh Redmond dan Bohnsack (2007), yakin bahwa bank yang lebih besar menghadapi lebih banyak ancaman dari asimetri informasi. Di sisi lain, penelitian dari Bourke dan DeYoung (1997) menunjukkan hubungan yang berlawanan antara ukuran bank dan profitabilitas bank, menjelaskan bahwa dengan kumpulan modal yang lebih besar, bank dapat melakukan investasi yang lebih baik dan menghindari biaya kebangkrutan.

\section{HASIL PENELITIAN DAN PEMBAHASAN}

Hasil statistik deskriptif (Tabel 2) menunjukkan bahwa profitabilitas bankumum yang diukur dengan ROA memiliki mean $0,31 \%$ dan fluktuasi nilai sisa di sekitar nilai mean adalah 0,32323 . Tingkat profitabilitas tertinggi $10,61 \%$ dan terendah negatif $-17,06 \%$.

Tabel 2. Hasil Statistik Deskriptif

\begin{tabular}{cccccccc}
\hline Variabel & Range & Minimum & Maximum & Sum & Mean & Std. Deviation & Variance \\
\hline ROA & 27,66 & $-17,06$ & 10,61 & 32,67 & 0,31 & 3,31 & 10,96 \\
ROE & 67,08 & $-37,00$ & 30,08 & 349,31 & 3,33 & 11,21 & 125,69 \\
LDR & 1,04 & 0,01 & 1,05 & 67,01 & 0,64 & 0,14 & 0,02 \\
BANKSIZE & 2,93 & 12,23 & 15,16 & 1433,12 & 13,65 & 0,79 & 0,64 \\
DEPOSIT & 27,51 & 0,02 & 27,53 & 197,19 & 1,88 & 4,49 & 20,23 \\
EQUITY & 0,70 & 0,05 & 0,75 & 18,93 & 0,18 & 0,11 & 0,01 \\
\hline
\end{tabular}

Sumber: Data Diolah

Uji multikolinearitas digunakan untuk menguji variabel-variabel independen dalam model penelitian memiliki hubungan linier. Jika indeks VIF lebih besar dari 5, ada tingkat multikolinearitas yang tinggi antar variabel. Hasil penelitian menunjukkan VIF kurang dari 5 
yang berarti tidak ada linearitas antar variabel bebas. Oleh karena itu, variabel-variabel tersebut dapat digunakan untuk analisis regresi. Pada uji heteroskedastisitas, diperoleh gambar scatterplot menunjukkan penyebaran titik tidak membentuk pola. Berdasarkan hasil tersebut disimpulkan model telah terhindar dari gejala heteroskedastisitas. Hasil uji normalitas menggunakan metode Monte Carlo, uji normalitas di lakukan dengan menggunakan nilai residual dari hasil uji regresi. Menurut Singgih Santoso (2014), data dikatakan berdistribusi normal (simetris) dalam uji normalitas data di katakan terdistribusi normal jika nilai signifikasinya $>0.05$. Uji normalitas pada residual regresi dependen variable ROA sudah terditribusi normal dengan nilai signifikansi 0.067 dan pada residual regresi dependen variable ROE juga sudah terdistribusi normaldengan nilai 0.381 . Hasil pengujian regresi linier ditunjukkan pada Tabel 3 dan 4.

Tabel 3. Hasil Regresi Linier Berganda - variabel dependen ROA

\begin{tabular}{lcccl}
\hline \multicolumn{1}{c}{ Variabel } & Koefisien & t-statistik & Sig. & \multicolumn{1}{c}{ Keterangan } \\
\hline Konstanta & 12,38 & 3,99 & 0,00 & \\
ROE & 0,26 & 18,44 & 0,00 & signifikan pada taraf $\alpha=1 \%$ \\
LDR & 1,76 & 1,77 & 0,08 & signifikan pada taraf $\alpha=10 \%$ \\
Banksize & $-0,93$ & $-4,33$ & 0,00 & signifikan pada taraf $\alpha=1 \%$ \\
Deposit & 0,02 & 0,78 & 0,43 & tidak signifikan \\
Equity & $-8,12$ & $-5,82$ & 0,00 & signifikan pada taraf $\alpha=1 \%$ \\
\hline
\end{tabular}

Sumber: Data diolah

Tabel 4. Hasil Regresi Linier Berganda - variabel dependen ROE

\begin{tabular}{lcccl}
\hline \multicolumn{1}{c}{ Variabel } & Koefisien & t-statistik & Sig. & \multicolumn{1}{c}{ Keterangan } \\
\hline Konstanta & $-60,06$ & $-6,47$ & 0,00 & \\
LDR & $-3,09$ & $-0,93$ & 0,36 & tidak signifikan \\
Banksize & 4,45 & 7,02 & 0,00 & signifikan pada taraf $\alpha=1 \%$ \\
Deposit & $-0,14$ & $-1,49$ & 0,14 & tidak signifikan \\
Equity & 22,49 & 4,63 & 0,00 & signifikan pada taraf $\alpha=1 \%$ \\
ROA & 2,92 & 18,44 & 0,00 & signifikan pada taraf $\alpha=1 \%$ \\
\hline
\end{tabular}

Sumber: Data diolah

Hasil estimasi perubahan regresi menggunakan ukuran kinerja, ROA dan ROE, dan pengukuran risiko kinerja, SDROA dan SDROE diregresikan pada rasio pinjaman terhadap simpanan (LDR) dan variabel kontrol yang mana termasuk Ukuran Perusahaan, Deposito, Ekuitas, dan Profitabilitas selama periode COVID-19 untuk bank komersial. T- statistik berada dalam tanda kurung di bawah estimasi parameter. t-statistics dihitung menggunakan kesalahan standar yang kuat. Signifikansi statistik diukur pada tingkat 1\%, 5\%, dan 10\%. 
Berdasarkan Tabel 3 dan 4 dapat diketahui pengujian hipotesis kami menggunakan analisis regresi linier untuk mengetahui dampak diversifikasi pendapatan bank pada pendapatan non bunga terhadap profitabilitas bank dan resiko bank. Uji regresi di lakukan dengan menggunakan model regresi linier berganda.

Pada uji regresi dependen variabel ROA menunjukan beberapa hasil. Variabel dependen LDR menunjukan nilai yang signifikan pada tingkat signifikasi $10 \%$ dan berpengaruh positif pada ROA. Bank size dan equity juga menunjukan pengaruh yang signifikan pada tingkat signifikan $1 \%$. Bank zise berpengaruh negative terhadap ROA dan equity juga bepengaruh negatif pada ROA. Sementara ini deposit tidak menunjukan adanya pengaruh pada ROA.

Untuk variabel dependen ROE menunjukan hasil yang sedikit berbeda. Variabel independen LDR menunjukan tidak ada pengaruh terhadap ROE. Pengaruh yang signifikan hanya di tunjukan oleh bank size dan equity. Bank sise bepengaruh secara positif pada ROE begitu pula equity juga menunjukan pengaruh positif pada ROE. Variabel independen Deposit juga belum menunjukan adanya pengaruh terhadap ROE.

Hasil regresi diatas sejalan dengan pendapat dari (Do dkk, 2020) yang menyatakan bahwa ketika tingkat kredit bermasalah meningkat, ROA bank akan menurun, yang berarti profitabilitas bank akan turun. Adanya hubungan kredit bermasalah dengan profitabilitas diperbankan Indonesia selama masa pandemi ini membuat bank harus ektra hati hati dalam melakukan dan menaggulangi masalah kredit, agar profitabilitas bank tetap terjaga. Sementara untuk ROE masih belum menunjukkan adanya pengaruh terhadap kredit bermasalah.

\section{Simpulan}

Dalam studi ini, kami menganalisa selama pandemi COVID-19 untuk mengetahui hubungan antara risiko kredit bermasalah terhadap profitabilitas perbankan. Efek yang ditimbulkan akibat dari adanya pandemic Covid-19 ini adalah mengakibatkan perubahan standar kredit dan berkurangnya permintaan untuk berbagai jenis pinjaman. Hasil penelitian kami membuktikan bahwa variable kredit bermasalah berpengaruh terhadap ROA dan variable kredit bermasalah tidak berpengaruh terhadap ROE.

\section{REFERENSI}

Abreu, M., \& Mendes, V. (2002). Commercial Bank Interest Margins and Profitability. Andries, A. M. (2011). The determinants of bank efficiency and productivity growth in the Central and Eastern European banking systems. Eastern European Economics, 49(6), 38-59. 
Atemkeng, T., \& Nzongang, J. (2006). Market structure and profitability performance in the banking industry of CFA countries: The case of commercial banks in Cameroon.Journal of Sustainable Development in Africa, 8(2), 1-14.

Athanasoglou, P. P., Brissimis, S. N., \& Delis, M. D. (2008). Bank-specific, industry-specific and macroeconomic determinants of bank profitability. Journal of international financial Markets, Institutions and Money, 18(2), 121-136.

Auronen, L. (2003, May). Asymmetric information: theory and applications. In Seminar of Strategy and International Business as Helsinki University of Technology.

Banker, R. D., Chang, H., \& Lee, S. Y. (2010). Differential impact of Korean banking system reforms on bank productivity. Journal of Banking \& Finance, 34(7), 1450-1460.

Berger, A. N., \& DeYoung, R. (1997). Problem loans and cost efficiency in commercial banks. Journal of Banking \& Finance, 21(6), 849-870.

Bofondi, M., \& Gobbi, G. (2004). Bad loans and entry into local credit markets (Vol. 509). Banca d'Italia.

Demirgüç-Kunt, A., \& Huizinga, H. (1999). Determinants of commercial bank interest margins and profitability: some international evidence. The World Bank Economic Review, 13(2), $379-408$.

Do, H.L., Ngo, T.X., Phung, Q.A. (2020). The effect of non-performing loans on profitability of commercial banks: Case of Vietnam. Accounting. https://doi: 10.5267/j.ac.2020.1.001

Goudreau, R. E., \& Whitehead, D. D. (1989). FYI Commercial Bank Profitability: Improved In1988. Economic Review-Federal Reserve Bank of Atlanta, 74(4), 34.

Hancock, D. (1989). Bank profitability, deregulation, and the production of financial services (No. 89-16).

Hariyani, I. (2013). Restrukturisasi dan Penghapusan Kredit Macet (1st ed.). Kompas Gramedia.

Markowitz, H. (1952). Portfolio selection. The Journal of Finance, 7(1), 77-91.

Norris, H. (1945). Profit: Accounting theory and economics. Economica, 12(47), 125-133. Novalina, A. (2020). Indonesian Economy the Impact of COVID-19 (IHSG by ARDL). Jurnal Kajian Ekonomi dan Kebijakan Publik, 5(2), 247-259.

Odufulu, O. (1994). Monetary Policy and Banks' Profitability in Nigeria. First Bank ofNigeria Plc Bi-Annual Review.

Otoritas Jasa Keuangan (OJK). (n.d.). Statistik Perbankan Indonesia. Retrieved from https://www.ojk.go.id/id/kanal/perbankan/datadan-statistik/statistik-perbankan indonesia/Default.aspx

Pagano, M., \& Jappelli, T. (1993). Information sharing in credit markets. The journal of finance, 48(5), 1693-1718. 
Quang, L. (2015). Determinants of banking crisis: The case of Vietnam. Journal of Science, 4,64 .

Symss, J., Saradhi, V. R., \& Nehra, P. (2018). Determinants of Non-Performing Assets in Indian Banking Sector. The Management Accountant Journal, 53(7), 91-98.

Towpek, H., \& Borhan, J. T. (2006). Untung dalam sistem perbankan Islam. Islamic Banking and Finance Institute Malaysia (IBFIM).

Tri Apriyani. (2020). Dampak pandemic Covid-19 terhadap Nasib Perbankan dan Bank Perkreditan (msn.com).

Trujillo-Ponce, A. (2013). What determines the profitability of banks? Evidence from Spain. Accounting \& Finance, 53(2), 561-586.

Tulsian, M. (2014). Profitability analysis: A comparative study of SAIL \& TATA Steel. Journal of Economics and Finance (IOSR-JEF), 3(2), 19-22.

Uchendu, O.A. (1995). Monetary policy and the performance of commercial banking in Nigeria. Monograph, Research Department, CBN.

Vinh, N. T. H. (2017). The impact of non-performing loans on bank profitability and lending behavior: Evidence from Vietnam. Journal of Economic Development, (JED, Vol. 24 (3)), 27-44. 